\title{
BIOLOGICAL INTEGRITY OF
}

BIG DRY CREEK

BASED ON THE STRUCTURE AND COMPOSITION OF

THE BENTHIC ALGAE COMMUNITY

\author{
Prepared for: \\ State of Montana \\ Department of Environmental Quality \\ P.O. Box 200901 \\ Helena, Montana 59620-0901 \\ Project Officer: Rebecca Ridenour \\ DEQ Contract No. 200012-10
}

STATE documelis GGLeCr.

Prepared by:

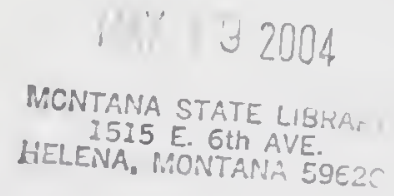

Loren L. Bahls, Ph.D.

Hannaea

1032 Twelfth Avenue

Helena, Montana 59601

February 9, 2004 
숭

웅 


\section{Summary}

On July 29, 2003, periphyton samples were collected from six sites on Big Dry Creek near Jordan, Montana for the purpose of assessing whether this stream is water-quality limited and in nced of TMDLs. The samples were collected following MDEQ standard operating procedures, processed and analyzed using standard methods for periphyton, and evaluated following modificd USEPA rapid bioassessment protocols for wadeable streams.

Diatom metrics indicate moderate impairment from sedimentation at the Mormon Church site and the sewage plant site, and moderate impairment from organic loading at the sewage plant site. The other four sites suffered minor impairment from organic loading and two of these sites (The Trees and Van Norman) suffered minor impairment from sedimentation.

All of the sites except The Trees were dominated by the filamentous green alga Rhizoclonium. This free-floating and mat-forming alga has been reported to cause problems in standing and slowly flowing waters in the western United States.

The Trees and the Mormon Church sites were similar and different from the other sites in that they supported a larger number of nitrogen-fixing algae, a larger percentage of nitrogen heterotrophs, a larger number of cool-water algae, and a larger number of algae that tolerate elevated levels of salinity. Nitrogen was probably the limiting nutrient at The Trees and the Mormon Church.

Algal communities at the Highway 200, Van Norman, and Near Mouth sites were similar in composition. At these sites, diatom metrics and algal composition indicated fresher waters, less organic loading, and less sedimentation than upstream. Most diatoms at all six sites indicate eutrophic conditions. 


\section{Introduction}

This report evaluates the biological integrity ${ }^{1}$, support of aquatic life uses, and probable causes of stress or impairment to aquatic communities in Big Dry Creek near Jordan in east central Montana. The purpose of this report is to provide information that will help the State of Montana determine whether Big Dry Creek is water-quality limited and in need of TMDLs.

The federal Clean Water Act directs states to develop water pollution control plans (Total Maximum Daily Loads or TMDLs) that set limits on pollution loading to water-quality limited waters. Water-quality limited waters are lakes and stream segments that do not meet waterquality standards, that is, that do not fully support their beneficial uses. The Clean Water Act and USEPA regulations require each state to (1) identify waters that are water-quality limited, (2) prioritize and target waters for TMDLs, and (3) develop TMDL plans to attain and maintain water-quality standards for all water-quality limited waters.

Evaluation of aquatic life use support in this report is based on the species composition and structure of periphyton (benthic algae, phytobenthos) communities at six sites that were sampled on July 29-30, 2003. Periphyton is a diverse assortment of simple photosynthetic organisms called algae that live attached to or in close proximity of the stream bottom. Some algae form long filaments or large colonies that are conspicuous to the unaided eye. But most algae, including the ubiquitous diatoms, can be seen and identified only with the aid of a microscope. The periphyton community is a basic biological component of all aquatic ecosystems. Periphyton accounts for much of the primary production and biological diversity in Montana streams (Bahls et al. 1992). Plafkin et al. (1989) and Barbour et al. (1999) list several advantages of using periphyton in biological assessments.

\footnotetext{
'Biological integrity is defined as "the ability of an aquatic ecosystem to support and maintain a balanced, integrated, adaptive community of organisms having a species composition, diversity, and functional organization comparable to that of natural habitats within a region" (Кап and Dudley 1981).
} 


\section{Project Area and Sampling Sites}

The project area is located in Garfield County in east central Montana. Big Dry Creek heads at an elevation of 3,500 feet south of Sand Springs in the southwestern comer of Garfield County. It flows north and then east to meet Little Dry Creek about 25 miles east of Jordan and just north of Montana Highway 200 near the Van Norman community. The combined flows of Little Dry and Big Dry Creeks then continue north into the Big Dry Arm of Fort Peck Reservoir on the Missouri River.

The project area is within the Northwestern Great Plains Ecoregion (Woods et al. 1999). The surface geology of the area consists of sandstone and shales of the Hell Creek Formation in the headwaters and near the mouth of Big Dry Creek, and rocks of the coal-bearing Fort Union Formation in between (Renfro and Feray 1972). The climate is semiarid and continental, with cold winters and hot, dry summers. Upland vegetation is predominantly mixed grassland steppe (USDA 1976). The main land use is livestock grazing.

Periphyton smples were collected at six sites on Big Dry Creek (Table 1). Elevations at the sampling sites range from 2,650 feet at The Trees to 2,350 feet near the mouth.

\section{Methods}

Periphyton samples were collected following standard operating procedures of the MDEQ Planning, Prevention, and Assistance Division. Using appropriate tools, microalgae were scraped, brushed, or sucked from natural substrates in proportion to the importance of those substrates at each study site. Macroalgae were picked by hand in proportion to their abundance at the site. All collections of microalgae and macroalgae were pooled into a common container and preserved with Lugol's (IKI) solution. 
The samples were examined to estimate the relative abundance and rank by biovolume of diatoms and genera of soft (non-diatom) algae according to the method described in Bahls (1993). Soft algae were identified using Smith (1950), Prescott (1962, 1978), John et al. (2002), and Wehr and Sheath (2003). These books also served as references on the ecology of the soft algae, along with Palmer $(1969,1977)$.

After the identification of soft algae, the raw periphyton samples were cleaned of organic matter using sulfuric acid, postassium dichromate, and 3\% hydrogen peroxide. Then, permanent diatom slides were prepared using Naphrax ${ }^{\mathrm{TM}}$, a high refractive index mounting medium, following Standard Methods for the Examination of Water and Wastewater (APHA 1998). Approximately $300-350$ diatom cells (600-700 valves) were counted at random and identified to species. The following were the main taxonomic references for the diatoms: Krammer and Lange-Bertalot 1986, 1988, 1991a, 1991b; Lange-Bertalot 2001; Krammer 2002. Diatom naming conventions followed those adopted by the Academy of Natural Sciences for USGS NAWQA samples (Morales and Potapova 2000). Van Dam et al. (1994) was the main ecological reference for the diatoms.

The diatom proportional counts were used to generate an array of diatom association metrics. A metric is a characteristic of the biota that changes in some predictable way with increased human influence (Barbour et al. 1999). Diatoms are particularly useful in generating metrics because there is a wealth of information available in the literature regarding the pollution tolerances and water quality preferences of common diatom species (e.g., Lowe 1974, Beaver 1981, Lange-Bertalot 1979, 1996, Van Dam et al. 1994).

Values for selected diatom metrics were compared to biocriteria (numeric thresholds) developed for streams in the Great Plains ecoregions of Montana (Table 2). These criteria are based on the distribution of metric values measured in least-impaired reference streams (Bahls et al. 1992) and metric values measured in streams that are known to be impaired by various sources and causes of pollution (Bahls 1993). The biocriteria in Table 2 are valid only for samples collected during the summer field season (June 21-September 21). 
The criteria in Table 2 distinguish among four levels of stress or impairment and three levels of aquatic life use support: (1) no impairment or only minor impairment (full support); (2) moderate impairment (partial support); and (3) severe impairment (nonsupport). These impairment levels correspond to excellent, good, fair, and poor biological integrity, respectively.

\section{Quality Assurance}

Several steps were taken to assure that the study results are accurate and reproducible. Upon receipt of the samples, station and sample attribute data were recorded in the Montana Diatom Database and the samples were assigned a unique number, e.g., 3013-01. The first part of this number (3013) designates the sampling site (Big Dry Creek at The Trees) and the second part (01) designates the number of periphyton samples that that have been collected at this site for which data have been entered into the Montana Diatom Database.

Sample observations and analyses of soft (non-diatom) algae were recorded in a lab notebook along with information on the sample label. A portion of the raw sample was used to make duplicate diatom slides. The slide used for the diatom proportional count will be deposited in the Montana Diatom Collection at the University of Montana Herbarium (MONTU) in Missoula. The duplicate slide will be retained in Helena at the offices of Hannaea. Diatom proportional counts have been entered into the Montana Diatom Database.

\section{Results and Discussion}

Results are presented in Tables 3, 4, and 5, which are located near the end of this report following the references section. Appendix A consists of a series of diatom reports, one for each sample. Each diatom report contains an alphabetical list of diatom species and their percent abundances, and values for 65 different diatom metrics and ecological attributes. 


\section{Sample Notes}

At The Trees. Fine particulate organic matter and very fine sediment were extremely abundant in this sample. The sample was anoxic and black but effectively cleared with $\mathrm{H} 202$

Near the Mormon Church. Fine particulate organic matter was abundant, as well as extremely heavy amounts of very fine to coarse inorganic sediment. The sample was anoxic and black and had a strong $\mathrm{H}_{2} \mathrm{~S}$ odor, but was cleared with $\mathrm{H}_{2} \mathrm{O}_{2}$

Sewage Treatment Plant. Extremely heavy amounts of very fine sediment were present. Macrophytes (slender, grass-like) were abundant. The sample smelled strongly of $\mathrm{H}_{2} \mathrm{~S}$, but was effectively cleared with $\mathrm{H}_{2} \mathrm{O}_{2}$.

Above Highway 200. Fine particulate organic matter and inorganic sediment (silt through sand-sized) were abundant. The sample was anoxic and black due to $\mathrm{H}_{2} \mathrm{~S}$, but was effectively cleared with $\mathrm{H}_{2} \mathrm{O}_{2}$.

Near Van Norman. Fine particulate organic matter and moderately coarse sediment were abundant. The sample anoxic and black due to $\mathrm{H}_{2} \mathrm{~S}$, but cleared with $\mathrm{H}_{2} \mathrm{O}_{2}$.

Near Mouth. Extremely heavy amounts of fine to very fine sediment were present. The sample was anoxic and black due to $\mathrm{H}_{2} \mathrm{~S}$, but cleared with $\mathrm{H}_{2} \mathrm{O}_{2}$.

\section{Non-Diatom Algae (Table 3)}

All six sites on Big Dry Creek except one-Highway 200-supported the usual mix of diatoms, green algae and cyanobacteria found in prairie streams. Cyanobacteria were absent from the sample collected at the Highway 200 site (Table 3 ). 
Samples from all sites except The Trees were dominated by the free-floating and matforming filamentous green alga Rhizoclonium. This alga has been reported to cause problems in standing and slowly flowing waters across the western United States (Wehr and Sheath 2003). Algae interfere with water uses-e.g., fishing, swimming, boating, and irrigation - only when standing crops are excessive. Mat-forming filamentous algae are normal components of many aquatic ecosystems, including prairie streams, and there is no evidence from this study that standing crops of Rhizoclonilum in Big Dry Creek are excessive. Also, criteria have not been established for determining when algal growth in prairie streams is excessive.

Instead of Rhizoclonium, Tribonema dominated the sample collected at The Trees. Tribonema is a filamentous chrysophyte that prefers cool waters. Also present and frequent at The Trees was Cladophora, a filamentous green alga that prefers cooler temperatures than Rhizoclonium. Besides Tribonema, three genera of algae were found exclusively at The Trees: Lyngbya, Vaucheria and Spirogyra. Lyngbya is a nitrogen-fixing cyanophyte and its presence here may indicate nitrogen-deficient waters. Vaucheria, a filamentous chrysophyte, requires steady flows of cool water. It is common in springs and spring brooks. Spirogyra, or "pond scum", is a free-floating filamentous green alga that is common in quiet backwaters. The Trees site supported the most diverse and the most unique assemblage of non-diatom algae.

Samples from near the sewage plant and at Highway 200 contained the fewest number of nondiatom algae (3). This may be a sign of stress, perhaps resulting from wastewater discharges and/or non-point sources of pollution. The absence of cyanobacteria (aka blue-green algae) at Highway 200 and their rarity downstream may be in response to nitrogen loading. Genera of cyanobacteria that have heterocysts, including Calothrix, Lyngbya, and Nodularia, are capable of fixing atmospheric nitrogen and have a competitive advantage when dissolved nitrogen is in short supply. Heterocysts are thick-walled cells specialized for fixing nitrogen. Genera of cyanobacteria that lack heterocysts (e.g., Oscillatoria) are capable of fixing atmospheric nitrogen under anaerobic conditions.

\section{Diatoms (Table 4)}


Of the 16 major diatom species in Big Dry Creek, only 1 is sensitive to organic pollution (class 3 ) and 3 are most tolerant of organic pollution (class 1). The remaining 12 major species are somewhat tolerant of organic pollution and these (class 2) species were abundant at all sites.

The Trees. Diatom metrics indicate that this site suffered from minor impairment due to organic loading and sedimentation (Table 4). The dominant diatom species here-Nitzschia inconspicua-is a eutraphentic species that is somewhat tolerant of organic enrichment. The Trees site supported the smallest species richness and species diversity values of all the sites, which may result from competition for available nutrients (see below).

This site supported the largest percentage of Rhopalodiales, which is the order of diatoms that harbor nitrogen-fixing endosymbionts (cyanobacteria). The abundance of diatoms in this group, together with the presence of Lyngbya, indicates likely nitrogen-limiting conditions at this site. Percent Rhopalodiales declined downstream to a value of 0 at the sewage treatment plant, then recovered to low levels farther downstream.

Mormon Church. A large percentage of motile diatoms indicated moderate impairment from sedimentation at this site and only partial support of aquatic life uses. Minor impairment from organic loading was also noted here. This site supported the second largest percentage of diatoms in the order Rhopalodiales, which indicates that nitrogen was probably still limiting here. The Mormon Church site shared over $70 \%$ of its diatom assemblage with The Trees site and the two sites were virtually indistinguishable, both floristically and ecologically. Both sites were dominated by Nitzschia inconspicua and Nitzschia filiformis. The latter species is a brackish water diatom that was found in abundance only at these two sites. Its decline at the sewvage plant and downstream may indicate dilution in Big Dry Creek by discharges of fresher water or by water of different ionic content.

Sewage Plant. This site had the lowest biological integrity and worst water quality of all the sites. Diatom metrics indicate moderate impairment and partial support of aquatic life uses due to organic loading and sedimentation (Table 4). Two diatom species that are very tolerant of organic pollution-Biremis circumtexta and Nitzschia palea - were most abundant here. In 
addition to tolerance of organic loading, B. circumtexta also tolerates elevated salinity levels. As a nitrogen heterotroph, Nitzschia palea can use preformed organic matter as a source of nitrogen. The sewage plant site did not support any nitrogen-fixing diatoms and shared only about onethird of its diatom association with the Mormon Church site just upstream.

Highway 200. This site had much improved biological integrity and water quality compared to the sewage plant site and suffered only minor impairment from organic loading, although it did support a large percentage of the pollution-tolerant species Gomphonema parvulum. The Highway 200 site shared less than 30 percent of its diatom assemblage with the upstream site at the sewage plant (Table 4). The Highway 200 site shared $37 \%$ and $33 \%$ of its diatom assemblage with The Trees and the Mormon Church sites, respectively.

Van Norman. This site was very similar to the Highway 200 site both floristically and ecologically (Table 4). Diatom metrics indicate only minor impairment from organic loading and sedimentation. The sedimentation index here was just above the threshold (50.00) for minor impairment. The Van Norman site supported the largest percentage of nitrogen-fixing diatoms below the sewage plant.

Near Mouth. This site was similar to the next two sites upstream and registered only minor impairment from organic loading. Diploneis puella was the dominant diatom species at all three sites. Diploneis puella is a motile, alkaliphilous, mesotraphentic, nitrogen autotroph that requires high levels of dissolved oxygen and tolerates only small amounts of organic matter (Van Dam et al. 1994). Nitzschia reversa ranked second in abundance near the mouth. This is a tychoplanktonic diatom that produces large populations in quiet waters (pools). This site had the largest diatom species richness and diversity values of all the sites sampled on Big Dry Creek (Table 4).

\section{Modal Categories (Table 5)}


Several ecological attributes were selected from the diatom reports in the appendix and modal categories of these attributes were extracted to characterize water quality tendencies at the six sites on Big Dry Creek (Table 5).

Modal categories were identical for the The Trees and the Mormon Church. Most diatoms at these sites were highly motile, alkaliphilous, eutraphentic, and facultative nitrogen heterotrophs that indicate brackish-fresh waters with $25-70 \%$ dissolved oxygen saturation and 4$13 \mathrm{mg} / \mathrm{L} \mathrm{BOD}_{5}$ (Van Dam et al. 1994). The modal category for oxygen demand was "moderate" ( $>50 \%$ saturation) at these sites. Modal categories at the sewage plant remained the same except for the nitrogen uptake and oxygen demand categories, which were "not classified".

At Highway 200 and downstream, modal categories indicated water quality improvement for sedimentation, salinity, and nutrient loading (Table 5). At these sites, most diatoms were only moderately motile instead of highly motile (exception: Van Norman site), nitrogen autotrophs instead of facultative nitrogen heterotrophs, and indicated fresh waters instead of brackish-fresh waters. The modal category for trophic state was eutraphentic at all stations.

\section{References}

APHA. 1998. Standard Methods for the Examination of Water and Wastewater. 20 th Edition. American Public Health Association, Washington, D.C.

Bahls, L.L. 1979. Benthic diatom diversity as a measure of water quality. Proceedings of the Montana Academy of Sciences 38:1-6.

Bahls, L.L. 1993. Periphyton Bioassessment Methods for Montana Streams (revised). Montana Department of Health and Environmental Sciences, Helena.

Bahls, L.L., Bob Bukantis, and Steve Tralles. 1992. Benchmark Biology of Montana Reference Streams. Montana Department of Health and Environmental Sciences, Helena.

Barbour, M.T., J. Gerritsen, B.D. Snyder, and J.B. Stribling. 1999. Rapid Bioassessment Protocols for Use In Streams and Wadeable Rivers: Periphyton, Benthic Macroinvertebrates and Fish. Second Edition. EPA/841-B-99-002. U.S. Environmental Protection Agency, Office of Water, Washington, D.C. 
Beaver, Janet. 1981. Apparent Ecological Characteristics of Some Common Freshwater Diatoms.

Ontario Ministry of The Environment, Technical Support Section, Don Mills, Ontario.

Johansen, J.R. 1999. Diatoms of Aerial Habitats. Chapter 12 in Stoermer, E.F., and J.P. Smol (eds.), The Diatoms: Applications For the Environmental and Earth Sciences, Cambridge University Press, New York.

John, D.M., B.A. Whitton, and A.J. Brook (eds.). 2002. The Freshwater Algal Flora of the British Isles: An Identification Guide to Freshwater and Terrestrial Algae. Canbridge University

Karr, J.R., and D.R. Dudley. 1981. Ecological perspectives on water quality goals. Environmental Management 5:55-69.

Krammer, Kurt. 2002. Cymbella. Volume 3 in Diatoms of Europe, Horst Lange-Bertalot, ed. A.R.G. Gantner Verlag K.G., Germany.

Krammer, K., and H. Lange-Bertalot. 1986. Bacillariophyceae, Part 2, Volume I: Naviculaceae. In Ettl, H., J Gerloff, H. Heynig, and D. Mollenhauer (eds.), Freshwater Flora of Middle Europe. Gustav Fischer Publisher, New York.

Krammer, K., and H. Lange-Bertalot. 1988. Bacillariophyceae, Part 2, Volume 2: Bacillariaceae, Epithemiaceae, Surirellaceae. In Ettl, H., J. Gerloff, H. Heynig, and D. Mollenhauer (eds.), Freshwater Flora of Middle Europe. Gustav Fischer Publisher, New York.

Krammer, K., and H. Lange-Bertalot. 199la. Bacillariophyceae, Part 2, Volume 3: Centrales, Fragilariaceae, Eunotiaceae. In Ettl, H., J. Gerloff, H. Heynig, and D. Mollenhauer (eds.), Freshwater Flora of Middle Europe. Gustav Fischer Publisher, Stuttgart.

Krammer, K., and H. Lange-Bertalot. 1991b. Bacillariophyceae, Part 2, Volume 4: Achnanthaceae, Critical Supplement to Navicula (Lineolatae) and Gomphonema, Complete List of Literature for Volumes 1-4. In Ettl, H., G. Gartner, J. Gerloff, H. Heynig, and D. Mollenhauer (eds.), Freshwater Flora of Middle Europe. Gustav Fischer Publisher, Stuttgart.

Lange-Bertalot, Horst. 1979. Pollution tolerance of diatoms as a criterion for water quality estimation. Nova Hedwigia 64:285-304.

Lange-Bertalot, Horst. 1996. Rote Liste der limnischen Kieselalgen (Bacillariophyceae) Deutschlands. Schr.-R. f. Vegetationskde., H. 28, pp. 633-677. BfN, Bonn-Bad Godesberg.

Lange-Bertalot, Horst. 2001. Navicula sensu stricto: 10 Genera Separated from Navicula sensu lato; Frustulia. Volume 2 in Diatoms of Europe, Horst Lange-Bertalot, ed. A.R.G. Gantner Verlag K.G., Germany.

Lowe, R.L. 1974. Environmental Requirements and Pollution Tolerance of Freshwater Diatoms. EPA-670/4-74-005. U.S. Environmental Protection Agency, National Environmental Research Center, Office of Research and Development, Cincinnati, Ohio.

McFarland, B.H., B.H. Hill, and W.T. Willingham. 1997. Abnormal Fragilaria spp. (Bacillariophyceae) In streams impacted by mine drainage. Journal of Freshwater Ecology 12(1):141-149.

Morales, E.A., and Marina Potapova. 2000. Third NAWQA Workshop on Harmonization of Algal Taxonomy, May 2000. Patrick Center for Environmental Research, The Academy of Natural Sciences, Philadelphia.

Palmer, C.M. 1969. A composite rating of algae tolerating organic pollution. Journal of Phycology 5:78-82.

Palmer, C.M. 1977. Algae and Water Pollution: An lllustrated Manual on the Identification, Significance, and Control of Algae in Water Supplies and in Polluted Water. EPA-600/9-77-036. 
Plafkin, J.L., M.T. Barbour, K.D. Porter, S.K. Gross, and R.M. Hughes. 1989. Rapid Bioassessment Protocols for Use in Rivers and Streams: Benthic Macroinvertebrates and Fish. EPA 440-4-89-001.

Prescott, G.W. 1962. Algae of the Western Great Lakes Area. Wm. C. Brown Company, Dubuque, Iowa.

Prescott, G.W. 1978. How to Know the Freshwater Algae. Third Edition. Wm. C. Brown Company Publishers, Dubuque, lowa.

Renfro, H.B., and D.E. Feray. 1972. Geological Highway Map of the Northern Rocky Mountain Region. American Association of Petroleum Geologists, Tulsa, Oklahoma.

Smith, G.M. 1950. The Fresh-Water Algae of The United States. McGraw-Hill Book Company, New York.

Stevenson, R.J., and Y. Pan. 1999. Assessing Environmental Conditions in Rivers and Streams with Diatoms. Chapter 2 in Stoermer, E.F., and J.P. Smol (eds.), The Diatoms: Applications For the Environmental and Earth Sciences, Cambridge University Press, New York.

Stewart, W.D.P., P. Rowell, and A.N. Rai. 1980. Symbiotic Nitrogen-Fixing Cyanobacteria. Pp. 239-277 in Stewart, W.D.P., and J. Gallo (eds.), Nitrogen Fixation, Academic Press, New York.

USDA. 1976. Climax Vegetation of Montana (map). U.S. Department of Agriculture, Soil Conservation Service, Cartographic Unit, Portland.

USEPA. 2000. Level III Ecoregions of the Continental United States (map). U.S. Environmental Protection Agency, Corvallis, Oregon.

Van Dam, Herman, Adrienne Mertens, and Jos Sinkeldam. 1994. A coded checklist and ecological Indicator values of freshwater diatoms from The Netherlands. Netherlands Journal of Aquatic Ecology 28(1):117-133.

Weber, C.I. (ed.). 1973. Biological Field and Laboratory Methods for Measuring the Quality of Surface Waters and Effluents. EPA-670/4-73-001. U.S. Environmental Protection Agency, National Environmental Research Center, Office of Research and Development, Cincinnati, Ohio.

Wehr, J.D., and R.G. Sheath. 2003. Freshwater Algae of North America: Ecology and Classification. Academic Press, New York.

Whittaker, R.H. 1952. A study of summer foliage insect communities in the Great Smoky Mountains. Ecological Monographs 22:1-44.

Woods, A.J., Omernik, J.M., Nesser, J.A., Shelden, J., and S.H. Azevedo. 1999. Ecoregions of Montana (color poster with map), U.S. Geological Survey, Reston, Virginia. 


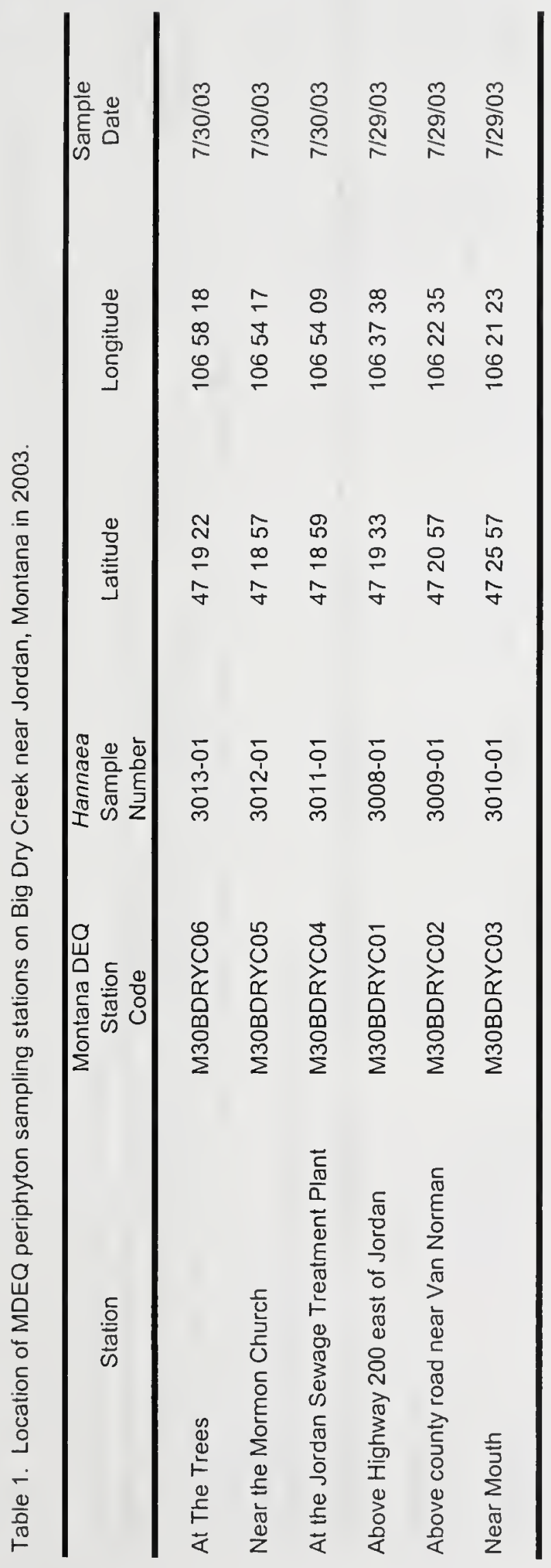




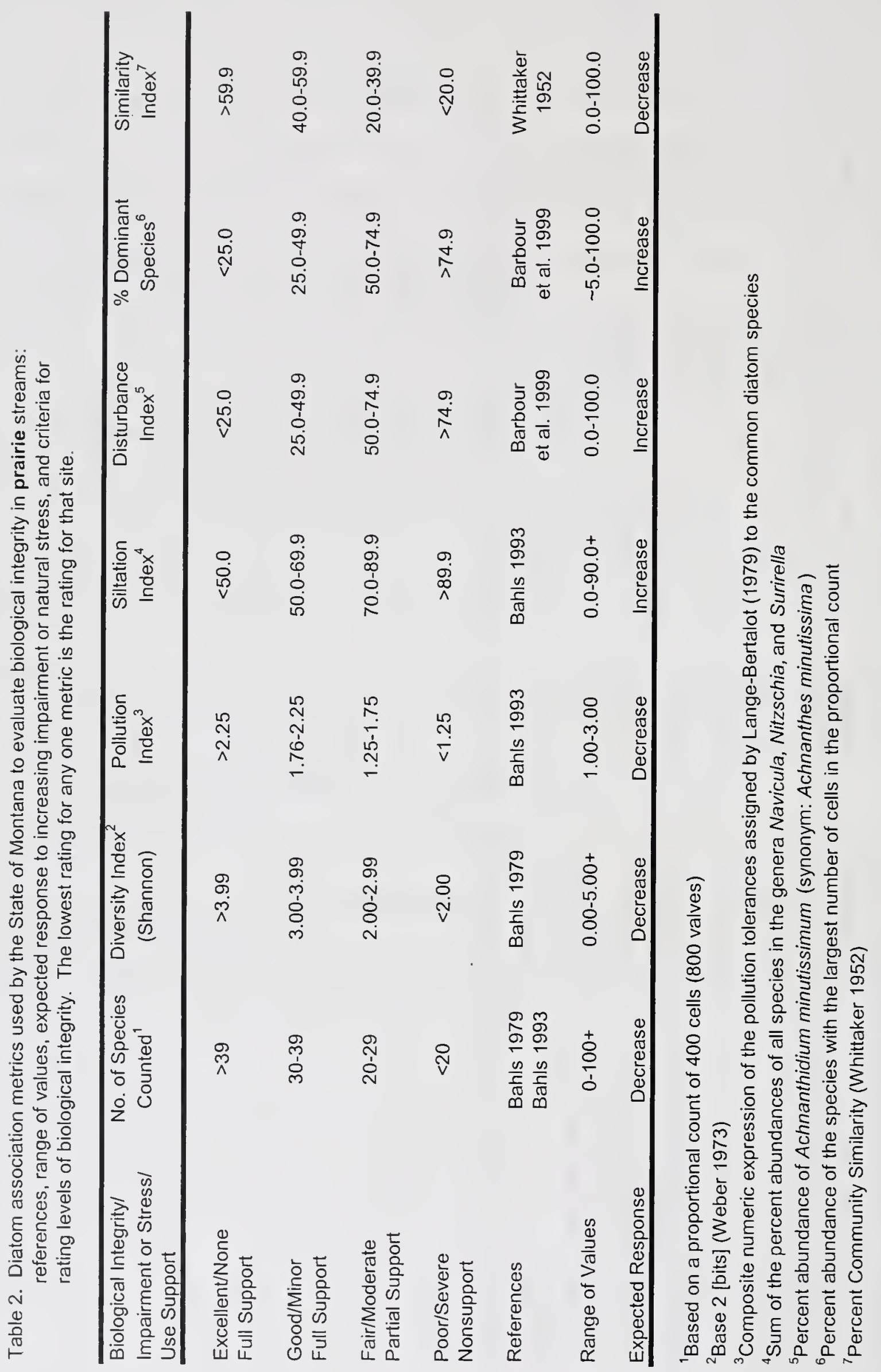




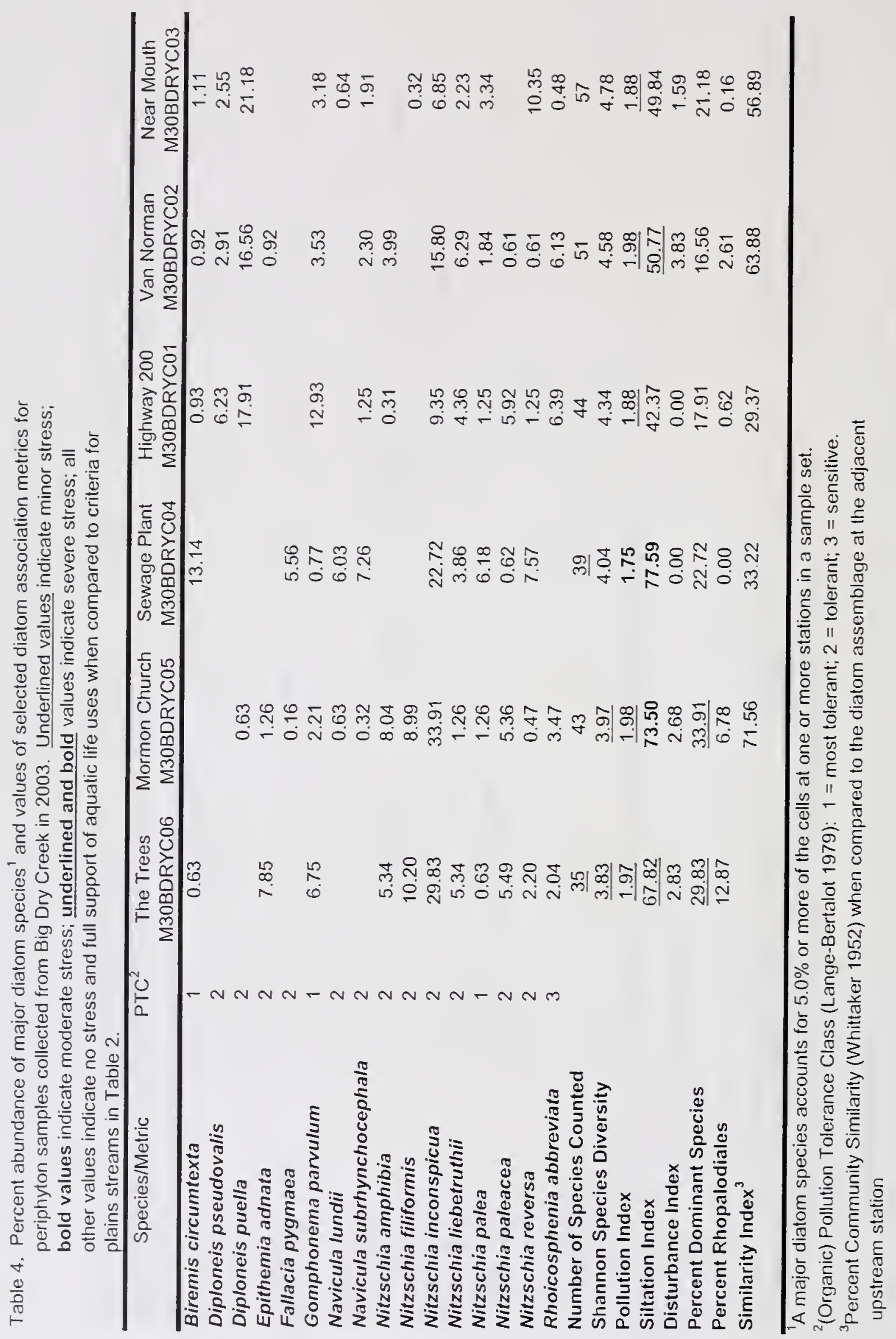




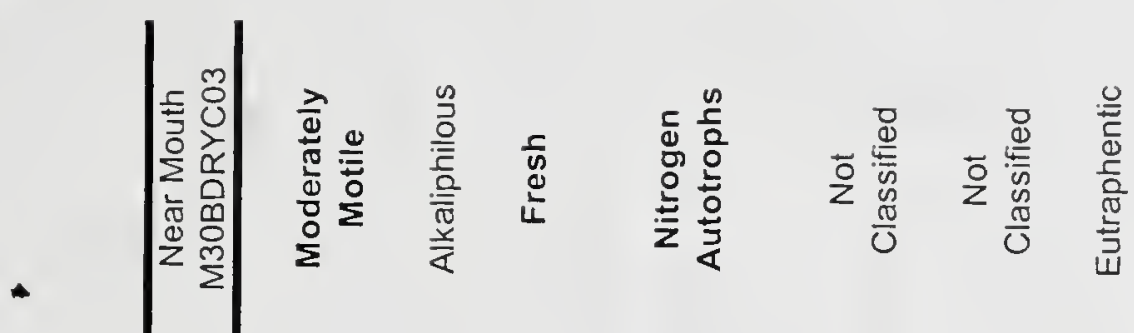

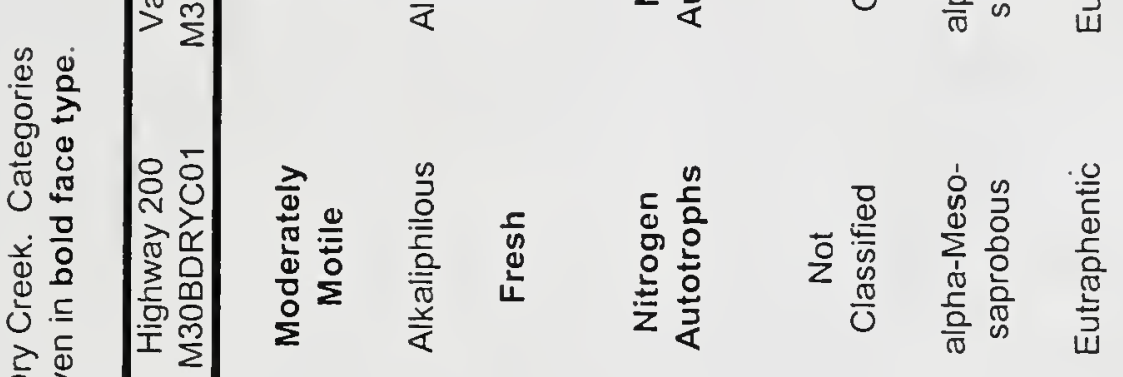

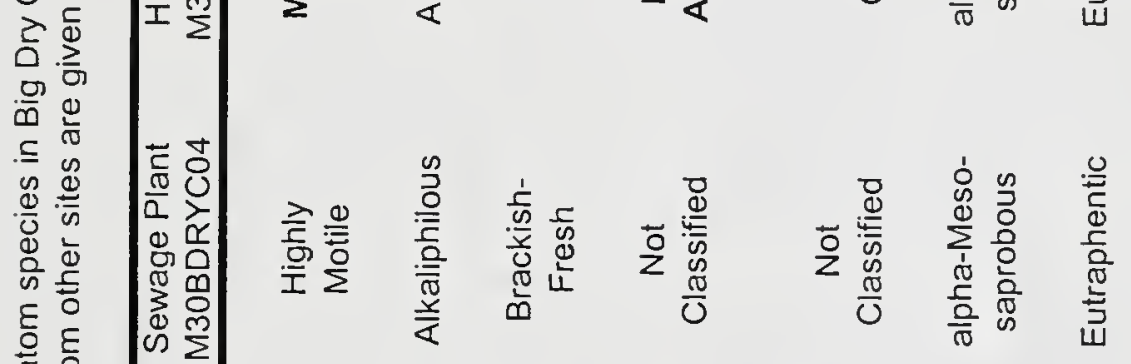

$$
\begin{aligned}
& \text { 음 } \\
& \text { 는 } \\
& \text { \& ํำ } \\
& \text { 告 } \\
& \overline{\mathrm{J}} . \subseteq \\
& \text { 음 든 }
\end{aligned}
$$

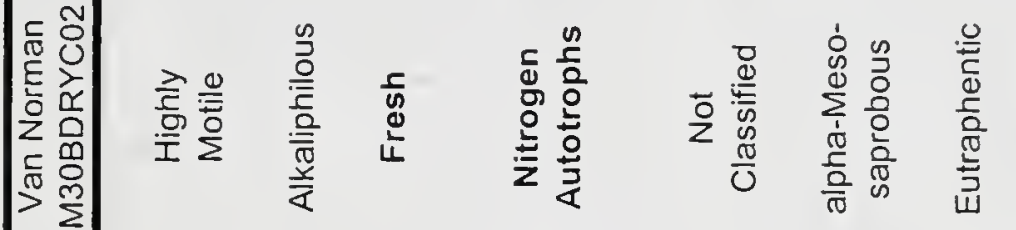

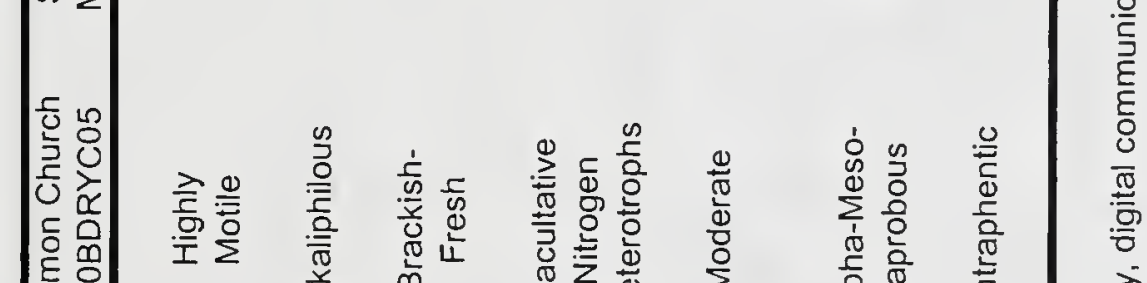

$$
\begin{aligned}
& \text { 응 } \\
& \text { (1) } \\
& \text { 总 . } \\
& \text { क त } \\
& \text { 은. } \\
& \text { \&. 드 } \\
& \text {. n }
\end{aligned}
$$

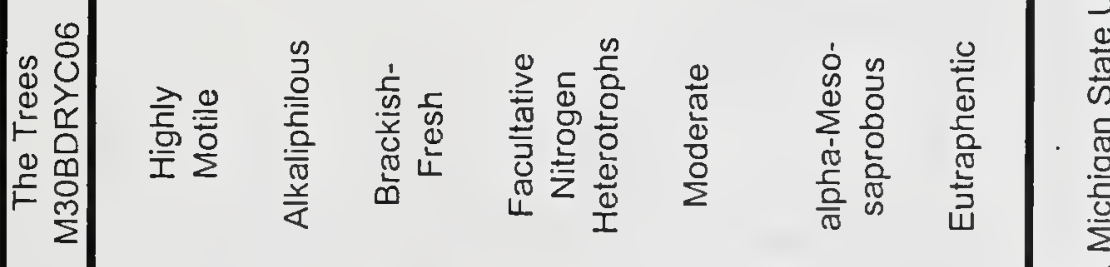

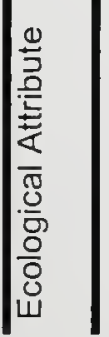

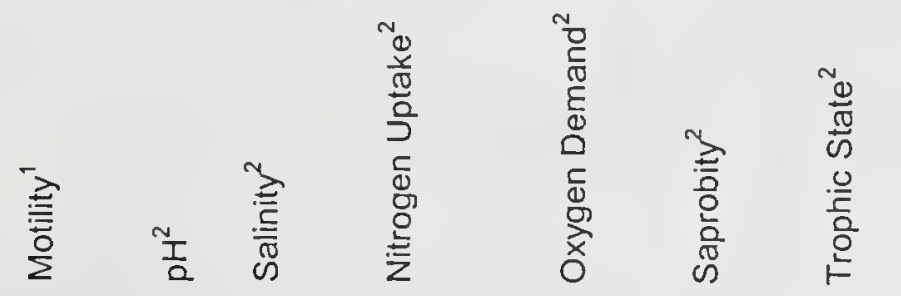

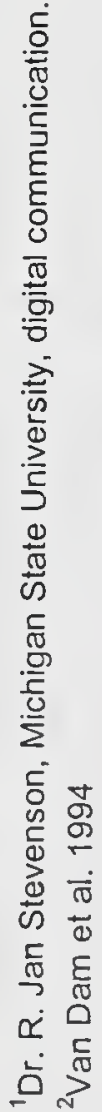



